\title{
Post-Secondary Distance Education in a Contemporary Colonial Context: Experiences of Students in a Rural First Nation in Canada
}

Jesse Simon ${ }^{1}$, Kevin Burton ${ }^{2}$, Emily Lockhart ${ }^{3}$, and Susan O'Donnell ${ }^{3}$

${ }^{1}$ Elsipogtog First Nation, Canada, ${ }^{2}$ Mi'kmaw Kina'matnewey, Canada, ${ }^{3}$ University of New Brunswick, Canada

\section{Abstract}

Post-secondary distance education gives students and their families living in remote and rural regions the option to stay in their communities while they study instead of moving closer to the universities in cities. Post-secondary distance education is an option in many rural and remote First Nation (Indigenous) communities in Canada; however there are many challenges to successful adoption in these communities. There are also many opportunities for post-secondary institutions to expand their abilities and capacity in developing and delivering appropriate content supporting these unique, selfgoverning environments in Canada. We explore the experiences of students from a rural First Nation in Canada with post-secondary distance education, focusing on how different delivery methods offer both opportunities and challenges for communitybased students. The study is situated in the context of contemporary colonialism in Canada.

Keywords: Post-secondary distance education; videoconference; web-based; learner preferences; First Nation; Indigenous; Aboriginal; communities; rural; Canada; colonialism 


\section{Introduction}

\section{The Political Context of Post-Secondary Distance Education in First Nations}

Post-secondary distance education gives students and their families living in remote and rural regions the option to stay in their communities while they study instead of moving to the cities where the institutions are based. Families that stay contribute to their community's social and economic capital. Ensuring that appropriate post-secondary distance education is available becomes an important element in the long-term sustainability of remote and rural communities. This research reports on the postsecondary education experiences of students in a rural First Nation and the need for appropriate learning opportunities in the Canadian contemporary colonial environment.

First Nations are politically autonomous Indigenous communities in Canada. With most of the more than 600 First Nations located in rural or remote areas, distance education would seem in theory to offer considerable benefits to community members. The Assembly of First Nations (AFN), the main political organization representing the more than 600 First Nation Chiefs, supports post-secondary education as a priority essential to the sustainable development of First Nations although it has no specific policy on post-secondary distance education (AFN, 2010a).

In 1972, First Nations outlined the requirements for their own education system in their "Indian Control of Indian Education" paper. This document was updated by the AFN to be First Nations Control of First Nation Education (AFN, 2010b). Key requirements for a First Nations education system include First Nations languages, cultures, histories, philosophies, worldviews and values (AFN, 2010b). These objectives ensure that First Nations people will be leading the development and operation of their schools and education programs.

The need for First Nations to control their education systems and processes is rooted in the contemporary colonial relationship between First Nations and the Canadian state. More than a decade ago, the Canadian government's most extensive Royal Commission of inquiry found that the historical treaties between the Crown and First Nations were replaced with Canadian policies intending to remove Aboriginal people from their homelands, suppress Aboriginal nations and their governments, undermine Aboriginal cultures, and stifle Aboriginal identity (Royal Commission on Aboriginal Peoples, 1996). Government policies continue to have an explicit goal to remove First Nations from remote and rural regions so that the lands and resources can be exploited for commercial industries such as mining and forestry (Alfred, 2009; Coulthard, 2007; Palmater, 2011).

In this context, distance education can mitigate the destructive effects of government 
policies designed to remove remote and rural First Nations people from their lands. Distance education using broadband networks allows First Nations to assert their sovereignty over their lands and resources and develop their communities with residents staying local (Beaton \& Campbell, in press). Post-secondary distance education has also been characterized as an opportunity to "decolonize cyberspace" (McAuley \&Walton, 2011).

McMullen and Rohrbach (2003) have identified "politics" as a primary barrier to distance education in remote First Nations. The political barriers include government underfunding of First Nations education and miring education programs in unnecessary bureaucracy. Within the university institutions, politics also plays a role in how educational programs are shaped to meet the needs of the instructors rather than the learners.

A second key barrier to distance education in remote First Nations is access to appropriate technology and delivery models (McMullen \& Rohrbach, 2003). By researching the needs of the students in First Nation communities and "adapting curriculum and technology to meet those needs, it is possible to correctly incorporate the appropriate technology" (McMullen \& Rohrbach, 2003, p. 61). However the political context just mentioned - including underfunding educational programs and designing programs to meet the needs of the institutions rather than the students - can present considerable constraints to successful distance education programs in remote and rural First Nations.

\section{Distance Education in Elsipogtog First Nation}

The current study explores how these issues play out in a rural First Nation in Canada. The Canadian provinces bordering the Atlantic Ocean are among the most rural regions of the country. Almost $50 \%$ of the residents of one of these provinces, New Brunswick, live in small rural communities (Statistics Canada, 2006). In this province there are 15 First Nation communities. Currently several universities in New Brunswick, as well as the neighbouring province of Nova Scotia and further afield, offer distance education to the First Nation community members. The courses are offered through videoconferencing or the web for individuals and groups in community classrooms. These different course delivery methods offer both opportunities and challenges for students who choose to study in the community where they live and work.

This exploratory study considers some of these opportunities and challenges. The study is based on interviews with community members of Elsipogtog First Nation in New Brunswick. Most community members interviewed had taken post-secondary courses by distance education while living and working in their community. The focus of the discussion is their experiences of distance education, in particular with videoconferencing and online web-based course delivery systems. 
The Elsipogtog First Nation study is part of a long-term research project investigating how remote and rural First Nations in Central and Eastern Canada are using broadband networks and information and communication technologies (ICT). This study is the first community-based research the project has conducted in the Atlantic region. Other communities that have collaborated with the project include Kitigan Zibi First Nation in Quebec (Whiteduck, Tenasco, O’Donnell, Whiteduck, \& Lockhart, in press; Lockhart, Tenasco, Whiteduck, O'Donnell, in press); Fort Severn First Nation in Ontario (Carpenter, Gibson, Kakekaspan, \& O’Donnell, in press; Gibson, Kakekaspan, Kakekaspan, O’Donnell, Walmark, Beaton, \& People of Fort Severn First Nation, 2012; O'Donnell, Kakekaspan, Beaton, Walmark, Mason, \& Mak, 2011), and Mishkeegogamang First Nation in Ontario (Gibson, Coulson, Miles, Kakekakekung, Daniels, \& O'Donnell, 2011; Gray-McKay, Gibson, O’Donnell, \& People of Mishkeegogamang, in press).

\section{Research on First Nation Students and Post-Secondary Distance Education}

Given that many First Nations are located in remote and rural areas of the country, distance education at post-secondary level is currently a hot topic for educators and their institutions wanting to understand how to best deliver courses and successfully engage students living in these communities. A comprehensive literature review conducted in preparation for this study found several overview reports and dozens of specific studies related to Aboriginal peoples in Canada and post-secondary education (Woodman Simmonds, Wasacase, \& O’Donnell, 2011).

In their review of distance education programs across the country, McMullen and Rohrbach (2003) found several innovative initiatives delivering high school and postsecondary education programs by distance delivery that have achieved dramatic success. However, few education institutions and education directors know of these successful models and few have been able to learn from these experiences. The best practices presented in their book are based on successfully developed and delivered distance education courses. These practices include the involvement of on-site tutors, flexible delivery models, and the need to develop personal relationships between the students and instructors.

A study conducted by Davis (2000) assesses distance education in Aboriginal communities in Canada and highlights future research possibilities. Her recommendations include: being clear on what distance education means; First Nations control over the distance education content and delivery of courses in their communities; and ensuring delivery modes with higher levels of interactivity (such as two-way audio and TV-conferencing) that support learning for students who prefer that mode. First Nation communities need to define their own educational priorities and determine the values and perspectives informed by their educational experiences. 
A comprehensive report on Aboriginal learning by the Canadian Council on Learning (2009) underscores the importance of broadband networks for providing distant education opportunities for people living in remote and rural First Nations. The report notes that no statistics are available to indicate the number of remote and rural First Nation community members who are taking distance education courses. The CCL report also highlights the importance of informal learning opportunities and learning styles that allow First Nation community members to share information and learn as a collective.

Much of the research on post-secondary distance education in Aboriginal communities highlights the need for it as well as the benefits (Ambler, 1999; Archibald, Hampton, \& Newton, 1995; Benham \& Stein, 2003; Carter \& Rukholm, 2009; Davis, 2000; Deer \& Hakansson, 2005; Downing, 2002; Epstein, 1995; Facey, 2001; Fahy, Steel, \& Martin, 2009; Faith \& Sturrock, 1990; Freeman \& Morore, 2007; Ives \& Aitken, 2008; Keast, 1997, 1995; McMullen \& Rorhbach, 2003; Rice-Green \& Dumbrill, 2005; Robinson, 1992; Russell, Gregory, Hultin, Care, \& Courtenay, 2005; Sanchez, Stucky, \& Richard, 1998; Sharpe, 1992; Sisco, 2010; Spronk, 1995; Spronk \& Radtke, 1988; Stonechild, 2006; Voyageur, 2001; Zapf \& Bastien, 2000). The primary benefit is obvious: Studying in the same community where you live with your families and work has many advantages over leaving the community to study elsewhere. The option to leave their community removes yet another person and continues the colonial aspiration of making the First Nations disappear.

Most of the studies reviewed are evaluations of university or college courses; several have considered the broader perspectives of First Nation students living in their communities. For example, Ives and Aitken (2008) discuss the outcomes of delivering social work education at a distance to community services staff members in Kahnawake First Nation near Montreal. Two courses were offered through the MoGill School of Social Work via McGill's MyCourse website. The approaches and technologies included readings, audio and video clips, reflection logs, quizzes and downloadable toolkits, and instructional support via email and videoconferencing. The authors concluded that communities need to be involved in curriculum development and course materials need to be adapted for First Nation communities otherwise social work could contribute to continued cultural imperialism and colonization. Many other studies that consider the wider social and political contexts of First Nations have come to the same conclusion.

In another example of research based on course evaluations, Russell, Gregory, Hultin, Care, and Courtenay (2005) studied the experiences of Aboriginal nursing students participating in an online nursing university degree program at the University of Manitoba. The courses used various delivery modalities, including videoconferencing, a web-based conferencing system, and email. Researchers emphasized the overall positive student experiences of remaining in their home communities for their educational programs. They also found challenges such as a loss of personal interaction with instructors, leading to diminished respect for the instructor, learners perceiving they were 
not learning but merely being programmed, and faculty members' lack of familiarity with the unique culture of distant sites (Russell, Gregory, Hultin, Care, \& Courtenay).

In a more recent study of Aboriginal post-secondary distance education based on course evaluations, McAuley and Walton (2011) looked at a novel M.Ed. program delivered only to Inuit students. Four of the 11 courses were delivered exclusively online. Technical challenges made it almost impossible to deliver the courses using synchronous videoconferencing because the bandwidth was not adequate and so the online component was asynchronous web-based delivery. A unique web platform was developed: Nunavut MEd Knowledge Forum environment. The student evaluation of this new platform was extremely positive. The authors attribute its success as a learning tool to its ability to share knowledge among learners and teachers in a seamless environment.

A comprehensive study that included 165 residents of four northern remote communities in Alberta included the participants' self-reported learning experiences and preferences, including their views of available delivery formats (Fahy, Steele, \& Martin, 2009). The authors concluded that the delivery of distance education to adult learners needs to respect the needs and preferences of the learners rather than asking them to make the most adjustments to the delivery methods, and that the delivery of distance learning needs to be compatible with their personal, family, and work-related realities (Fahy, Steele, \& Martin). Students taking post-secondary distance courses benefit from local support, primarily support from family members (Steele \& Fahy, 2011).

There has been limited community-based research conducted in First Nation communities to understand their members' experiences and course delivery preferences. In one of the few studies found of this kind, Johnston (2001), in an unpublished master's thesis, examined the experiences of Aboriginal women completing a full-time college program by computer-based distance learning. The analysis concluded that for these women to be successful in their distance education courses, education must not only be community-based, flexible, and holistic but also foster and nurture relationships between and among students and instructors. Teachers of successful students are themselves respectful of Aboriginal values and work to create interpersonal connectedness using the technology to bridge the geographical distances.

The current study of Elsipogtog First Nation community members explores their experiences of and perspectives on various distance education options such as videoconferencing and web-based systems. This exploratory article is based on an analysis of interviews with Elsipogtog First Nation community members. We plan to expand on this study in future papers to consider more issues raised by First Nation community members related to their experiences with distance education. 


\section{Profile of Elsipogtog First Nation and Education Levels of Community Members}

Elsipogtog First Nation, formerly called the Big Cove Band, is the largest Mi'kmaw First Nation in New Brunswick, Canada with a current population of almost 2,000 residents. Their community and traditional lands are part of the unceded territories covered by the Peace and Friendship treaties entered into in the 1700s with the colonial powers and their settlers. Elsipogtog or L'sipuktuk means River of Fire. The community and its members operate many community services - elementary school, Health and Wellness Center, Alcohol and Drug Treatment Center, recreational facility with an arena, youth centre with public computer access, community church, daycare and head start programs, Royal Canadian Mounted Police detachment, Gas Bar and Motor Inn, and a restaurant - as well as offering a variety of other activities to Elsipogtog First Nation community members.

The Elsipogtog First Nation territory is nine kilometres west of the village of Rexton and about 170 kilometres (a two to three-hour drive) east of Fredericton, the provincial capital that is home to two English-language universities, the University of New Brunswick and St. Thomas University.

The 2006 census recorded 1,285 adults (15 years of age and older) living in Elsipogtog First Nation. Of these community members, 65 had completed a university degree, 20 had a university certificate, and 385 had a trades or non-university certificate. The number of university graduates in 2006 was up 30\% from the 2001 census which had recorded a population of 1,100 adults. By any standards, this is a significant increase in completion of university studies. Clearly there is a keen interest and capacity in the growing Elsipogtog First Nation community for post-secondary education at both university and college levels. (Note: Data on educational levels for Elsipogtog from the 2011 Census were not released.)

\section{Study Methodology}

Our exploratory study was conducted in collaboration with Elsipogtog First Nation and in partnership with Atlantic Canada's First Nation Help Desk, Mi'kmaw Kina'matnewey, in Membertou First Nation, Cape Breton, Nova Scotia. The researchers visited Elsipogtog First Nation in November and December 2011 and interviewed 12 community members living and working in the First Nation. Most had experience with post-secondary distance education; several without this experience provided their views on the topic. In January 2012, researchers continued the study with eight Elsipogtog First Nation community members living in Fredericton who were students at either the University of New Brunswick or St. Thomas University. Several had experience with distance education and the others discussed why they had left the community for their 
university education. In total 20 Elsipogtog First Nation community members participated in interviews for the study.

To identify the research participants for the study, the researchers worked with a community research associate who selected participants via a convenience sample, community members known to the associate to be willing to participate in the study with experience of university education. The interviews followed a structured interview guide with 38 questions including prompts for discussion. The average interview time was 30 minutes and the interviews were recorded with the consent of participants. Sample interview questions include: What did you like about these distance education courses? Can you think of any way that the course could have been improved to increase your engagement with other students? Of the distance education courses you have taken how involved did you feel in the life of the classroom? The interview recordings were transcribed and the transcripts analyzed using N-Vivo software to look for common themes, primarily the experiences of students with different types of course delivery.

The research protocols were reviewed by the research ethics board of the researchers' home institution and follow the ethical guidelines for conducting research with First Nation communities outlined in the Tri-Council Policy Statement, TCPS2 (Canadian Institutes of Health Research, Natural Sciences and Engineering Research Council of Canada, and Social Sciences and Humanities Research Council of Canada, 2010).

\section{Students' Experiences with Post-Secondary Distance} Education in Elsipogtog First Nation

\section{Overview: Current Use of Post-Secondary Distance Education in the Community}

The overall number or percentage of Elsipogtog First Nation community members taking courses by distance education is unknown. As previously discussed, most of the current study participants had personal experience taking university courses via distance education. The universities they mentioned were St. Thomas University and the University of New Brunswick in Fredericton, New Brunswick, and Dalhousie University and Mount St. Vincent University in Halifax, Nova Scotia. These universities are located in the Atlantic region and so their program offerings would be familiar to community members seeking a university education. Also mentioned was the University of Arizona in the United States.

Popular bachelor degree programs that the study participants are or were enrolled in include Bachelor of Social Work (BSW), Bachelor of Education (B.Ed), and Bachelor of Nursing (BN). In addition to the main subject areas, these programs include courses such as English, mathematics and history among other subjects. Several students have 
taken courses in technology and Aboriginal education. In addition to post-secondary distance education, Elsipogtog First Nation works closely with New Brunswick Community College in both Moncton and the Miramichi to help students obtain their high school diploma via distance education.

Distance education in Elsipogtog First Nation is delivered through the use of two main technologies: web-based online courses and videoconferencing. Each is discussed in the next sections.

\section{Experiences with Course Delivery via Web-Based Online Systems}

The four universities in the Atlantic region that offer courses to the study participants use several web-based online systems for distance education. The most common one mentioned by Elsipogtog First Nation students is WebEx, a technology allowing live video and visual exchange via a computer and audio exchange (voice) using a computer or phone connection. Everyone connected to a session sees the same thing on the screen while someone is talking. Anyone who wants to appear visually to others will require a webcam connected to their computer. Community members also mentioned using Blackboard and Moodle, both learning management systems (LMS), the latter an opensource platform. These systems are accessed via the internet using desktop or laptop computers.

Some Elsipogtog First Nation students described WebEx as a 'virtual meeting place' that provides more flexibility than videoconferencing since it allows them to work from the comfort of their own home and have more control over scheduling the time that they work on courses. Some students explained that the convenience of WebEx technology was that they did not have to commute to get to the videoconferencing set up in a community classroom and could have more time with their family: "So at home you can just...it's you and your computer and there's no distractions around you" (Elsipogtog First Nation Community Member).

Others explained that they were able to participate in peer working groups by meeting in a computer lab designated for distance education set up in a community resource centre. In this lab students are able to utilize SMART board technology (an electronic blackboard) along with WebEx to create a classroom environment where they are able to work with and support one another with specific courses.

WebEx can be difficult to use by students with few computer skills and little or no computer training. For those who struggle with using computer technology because of their inexperience with it, taking courses in this way can be extremely challenging.

I was so alone. Oh my, I was so alone. Sitting by the computer and by the phone and, you know. No, I was literally sick to my stomach, that's how much I...I'm not 
a computer learner at all. (Elsipogtog First Nation Community Member)

There's no face-to-face. There's six people in that course I'm taking now. It's impersonal, I guess. (Elsipogtog First Nation Community Member)

\section{Experiences with Course Delivery via Videoconferencing}

Videoconferencing technology involves real-time exchange of audio and video streams over broadband networks. The type of videoconferencing referred to in this article uses dedicated room-based units rather than videoconferencing on a personal computer. This set-up allows students and professors to participate in face-to-face visual and audio contact. In most situations, the videoconferencing system is connecting a university with one or more First Nations communities. In each community students are together in a classroom and the professor is located at a distant university or at a First Nation location from where the professor is delivering the course content. Typically the visual connection is through a television and camera set up at the front of the classroom in all the community classrooms and the one university classroom. One or more microphones in each site allows for audio exchange among the students in different classrooms and the professor.

These room-based videoconferencing systems require technical support to monitor the bridge - the unit that connects the different sites with each other. Technical support is also required to be on-call at each site in case of connectivity or troubleshooting problems. However the systems themselves are generally easy to use by someone with minimal training.

Students who self-identified as 'visual learners,' requiring more interaction with professors and classmates, preferred videoconferencing over web-based learning. Videoconferencing also allows students to be engaged via live video and audio with students from multiple communities, thereby creating a good networking and support system.

Students' perceptions of and experiences of videoconferencing were mixed. Some liked it and some did not, as illustrated by the following quotes.

To me we were closer in videoconferencing so more of community than [WebEx] because ... Like we're all doing the same thing... we were closer. Like WebEx, to me, there's space there blocking. It's not as personal I don't think. (Elsipogtog First Nation Community Member)

The courses just seemed as though I was on my own for the whole thing-the whole six years. When it came time for....Thank God for one my classmates for math because 
that was one of my worst experiences-taking a math class through videoconferencing as I have a really hard time with math and the professor was really rude, for one. But, you know, he didn't take it into consideration that we were all adult students and who haven't been in school for years and didn't take into consideration that some of us had trouble with math. (Elsipogtog First Nation Community Member)

The set-up for videoconferencing also has its difficulties if there is a lack of technical support to facilitate the interaction. Some students shared that their experiences with videoconferencing were sometimes unpleasant and annoying due to delays. One community member noted "it depends on your Internet signal. If it's not good, then you're going to get a lot of pauses in between or the professor will sound different" (Elsipogtog First Nation Community Member).

\section{Input to Course Delivery Methods and Perceptions of Control of the Process}

None of the students believed they or other community members had any input into the way the courses were delivered or had any control over the process of post-secondary distance education. One student said:

Oh that would be excellent if they [the university] actually came and asked us. If they responded to our emails, even... because nobody ever really asked us for our input, like how could we make this better; how could we better serve you'. (Elsipogtog First Nation Community Member)

Several of the students interviewed believed that if the community members had more input into the course delivery, the community would feel more ownership of the process, and more community members would be taking the courses and be more comfortable using computers. One explained:

It's the same with children, if you get them involved in a process of developing it, they're more anxious to get involved. So I think if they had a say in how it's going to be delivered or what's going to be delivered, I think they would feel more like ownership towards [the courses]. (Elsipogtog First Nation Community Member) 


\section{Discussion and Conclusions}

The Elsipogtog First Nation community members who participated in our study had different learning styles and preferences. For some, the convenience of web-based systems worked well, especially if they had family responsibilities. Others who wanted more group interaction preferred a classroom setting connected by videoconference. Videoconferencing may be more suitable for some students with limited computer experience. In either case, the importance was highlighted of being part of a group of students with peer support opportunities.

Currently the universities offering courses to Elsipogtog First Nation students are primarily using web-based course delivery. None of the Elsipogtog First Nation community members interviewed had a choice about which technologies to use to match their learning preferences. The universities make the choices about the technologies used to deliver courses to First Nations community members, and the students felt they have no say about the choices the universities make.

Our study of the educational experiences of Elsipogtog First Nation community members provides a better understanding of their preferences and needs for postsecondary distance education. We would expect a similar range of experiences in other First Nations communities in the Atlantic region, although this exploratory study cannot be generalized more widely to other communities.

It should be noted that the technologies discussed in this article are not static in the sense that changes and upgrades in broadband networks can significantly affect the user experience of the distance education course delivery. Challenges to video communications in rural and remote Aboriginal communities have been previously researched (O'Donnell, Perley, Simms, \& Hancock, 2009). Some of the challenges using videoconferencing raised by several participants in the study - poor connectivity and lag time (latency) with the video feed - can be improved with higher bandwidth networks. Indeed, at the time the study was being conducted, the community was preparing to install its own fibre optic network. Significant improvements in connectivity afforded by fibre networks will no doubt improve the quality of the videoconferencing in Elsipogtog First Nation and may influence distance learning preferences in future.

As suggested earlier from previous research by Fahy, Steele, and Martin (2009), a conclusion of the current study is that the delivery of distance education needs to respect the preferences of adult learners rather than asking them to make the most adjustment to the delivery methods.

Similarly, Deer and Hakansson (2005) suggest that knowledge, information and communication are at the core of the emerging global information society. Knowledge, information and communication, however, are culturally defined concepts and expressions and information and communication technologies are cultural products of the society that developed them. First Nations have their own concepts of knowledge, 
information and communication and have developed their own forms of information and communication. Therefore First Nations need to take part in the information society on their own terms to be able to shape their future according to their unique needs. The current study strongly suggests that this would include making decisions about the ways distance education is delivered to meet the needs of diverse community members.

Our study findings suggest the possibility of an unreached pool of potential students in the community who may be more interested to participate in post-secondary distance education if more technology choices were offered. In particular, it would be worth exploring if a blended model of online web-based courses and videoconferencing could be tailored to meet their needs. It is important to recognize the unique circumstances of every student using these resources and understand that what works for one may not work for another. Developing course delivery models using a blend of different technologies to create a more positive learning experience for Elsipogtog First Nation community members will require additional funding and planning.

In future, Elsipogtog First Nation could work with the universities to explore possibilities for courses that blend not only web-based and videoconferencing technologies but also distance education with in-community options. It is entirely possible, for example, for a university instructor to travel to different First Nations in the Atlantic region and provide the instruction using both distance and in-person classroom education at different times during the academic year. This has even been tried in a limited way in the past.

Clearly there is significant room for the Elsipogtog First Nation community to take a more active role in determining how the university courses are offered by distance to their community members, including strategies to ensure that the different learning preferences and styles of the students are accommodated. Taking control of their own post-secondary learning opportunities, establishing partnerships with interested postsecondary institutions, and providing the required learning environments and student support systems are examples of successful distance learning models adopted in other First Nations. Each of these steps requires access to financial resources, people, and facilities that support local economic development. These local efforts help to move both the community and its partner institutions beyond the traditional colonial relationship and support local and regional development in a province that requires new innovative strategies to address its rural challenges.

Our study suggests that more support for and attention to the students' preferences for learning styles will lead to more successful distance education programs in these communities. This suggestion aligns with the concept of "First Nations Control of First Nations Education" advocated by the Assembly of First Nations. It also suggests that more appropriate post-secondary distance education options will allow more families to remain in remote and rural First Nations while they study instead of moving to the cities, contributing to the long-term sustainability of their communities. 


\section{Acknowledgements}

The research team would like to thank the leadership of Elsipogtog First Nation for inviting us into the community and making it possible for us to conduct the study. We would like to thank Marina Simon for being our community research liaison. A warm thank-you to all the community members who participated in the interviews; we are learning from your ideas, stories and experiences.

This research was conducted as part of the First Nations Innovation project: $\underline{\mathrm{http}: / / \mathrm{fn}-}$ innovation-pn.com funded by in-kind contributions from the partners - Keewaytinook Okimakanak, the First Nations Education Council, Atlantic Canada's First Nation Help Desk / Mi'kmaw Kina'matnewey and the University of New Brunswick - and by grants from the Social Sciences and Humanities Research Council of Canada (SSHRC). 


\section{References}

Alfred, G. T. (2009). Colonialism and state dependency. J ournal of Aboriginal Health, $5(2), 42-60$.

Ambler, M. (1999). Educating the Native student at a distance. Tribal College J ournal, Spring(3), 6-9.

Archibald, J., Hampton, E., \& Neuton, E. (1995). Organization of educational services in sparsely populated regions of Canada. Saskatoon, SK: Saskatchewan Indian Federated College.

Assembly of First Nations. (2010a). Taking action for First Nations post-secondary education: Access, opportunity and outcomes discussion paper. Ottawa: Assembly of First Nations.

Assembly of First Nations. (2010b). First Nations control of First Nation education: It's our vision, it's our time. Retrieved from http:// www.afn.ca/uploads/files/education/3.2010_july_afn_first_nations_co ntrol_of first nations education_final_eng.pdf

Beaton, B., \& Campbell, P. (in press). Settler colonialism and First Nations ecommunities. J ournal of Community Informatics.

Benham, M. K. P., \& Stein, W. J . (2003). The renaissance of American Indian higher education: Capturing the dream. Mahwah, NJ : Lawrence Erlbaum Associates, Inc.

Canadian Council on Learning. (2009). The state of Aboriginal learning in Canada: A holistic approach to measuring success. Ottawa.

Canadian Institutes of Health Research, Natural Sciences and Engineering Research Council of Canada \& Social Sciences and Humanities Research Council of Canada. (2010). Tri-council policy statement: Ethical conduct for research involving humans. Retrieved from http:// www.pre.ethics.gc.ca/ eng/ policypolitique/initiatives/tcps2-eptc2/ Default/

Carpenter, P., Gibson, K., Kakekaspan, C., \&O’Donnell, S. (in press). How women in remote and rural First Nation communities are using information and communication technologies. J ournal of Rural Community Development.

Carter, L., \& Rukholm, E. (2009). Partnering with an aboriginal community for health and education. Canadian J ournal of University Continuing Education, 35(1), 45-60.

Coulthard, G. (2007). Subjects of empire: Indigenous peoples and the 'politics of recognition' in Canada. Contemporary Political Theory, 6, 437- 460. 
Davis, L. (2000). Electronic highways, electronic classrooms: Distance education in Canada. In M. Brant Castellano, L. Davis \& L. Lahache (Eds.), Aboriginal education: Fulfilling the promise (pp. 224-250). Vancouver, BC: UBC Press.

Deer, K., \& Hakansson, A. (2005). An indigenous approach to bridging the digital divide project proposal. Education and the Knowledge Society, 161, 237-40.

Downing, R. (2002). Bridging Aboriginal digital and learning divides: Report on office of learning technologies support to Aboriginal communities. Ottawa: Human Resources and Social Development Canada, Office of Learning Technologies.

Epstein, R. (1995). Distance-delivered tertiary programs for Indigenous People in Canada, Australia and New Zealand. Saskatoon, SK: University of Saskatchewan.

Facey, E. (2001). First Nations and education by internet: The path forward, or back? The J ournal of Distance Education, 16(1), 113-125.

Fahy, P., Steele, N., \& Martin, P. (2009). Preferences of residents in four Northern Alberta communities regarding local post-secondary programming. IRRODL, 10(3). Retrieved from http:// www.irrodl.org/index.php/irrodl/article/ view/673/1302

Faith, K., \& Sturrock, J . (1990). Women and university distance education in Canada. Women's Education des femmes, 7(4), 16-19.

Freeman, K., \& Morore, J . (2007). Testing a new talking stick: An Indigenous community organization and a Canadian university try desktop videoconferencing in partnership. Society for Information Technology \& Teacher Education International Conference. San Antonio, Texas: AACE.

Gibson, K., Coulson, H., Miles, R., Kakekakekung, C., Daniels, E., \&O'Donnell, S. (2011). Conversations on telemental health: listening to remote and rural First Nations communities. Rural and Remote Health, 11, 1656 (Online).

Gibson, K., Kakekaspan, M., Kakekaspan, G., O’Donnell, S., Walmark, B., Beaton, B., \& the People of Fort Severn First Nation (2012, February). A history of communication by Fort Severn First Nation community members: From hand deliveries to virtual pokes. Proceedings of the iConference 2012. Toronto, Canada.

Gray-McKay, C., Gibson, K., O’Donnell, S., \& People of Mishkeegogamang (in press). Mishkeegogamang Tepacimowin Networks. J ournal of Community Informatics. 
Ives, N. G., \&Aitken, O. (2008) Technology and access: Responding to the social work education needs of First Nations and Inuit Communities. Social Work Education, 27, 683-692.

J ohnston, T. L. (2001). Experiences of female students completing a full-time aboriginal program by computer mediated communication (Unpublished master's thesis). Lakehead University, Thunder Bay, Canada.

Keast, D. A. (1997). Toward an effective model for implementing distance education programs. American J ournal of Distance Education, 11(2), 39-55.

Keast, D. A. (1995). Access to university studies: Implementing and evaluating multipoint videoconferencing. Canadian J ournal of Continuing University Education, 23(1), 29-47.

Lockhart, E., Tenasco, A., Whiteduck, T., O'Donnell, S. (in press). Information and communication technology for education in an Algonquin First Nation in Quebec. J ournal of Community Informatics.

McAuley, A., \&Walton, F. (2011). Decolonizing cyberspace: Online support for the Nunavet MEd. IRRODL, 12(4). Retrieved from http:// www.irrodl.org/index.php/irrodl/article/view/848/1837

McMullen, B., \& Rorhbach, A. (2003). Distance education in remote Aboriginal communities: Barriers, learning styles and best practices. Prince George, BC: College of New Caledonia Press.

Miller, J . (2000). Skyscrapers hide the heavens: A History of Indian-White relations in Canada (Third Edition). Toronto: University of Toronto Press.

O’Donnell, S., Kakekaspan, G., Beaton, B., Walmark, B., Mason, R., \& Mak, M. (2011). A new remote community-owned wireless communication service: Fort Severn First Nation builds their local cellular system with Keewaytinook Mobile. Canadian J ournal of Communication, 36(4), 663-673.

O’Donnell, S., Perley, S., Simms, D., \&Hancock, B-R. (2009).Video communication roadblocks facing remote Indigenous communities. IEEE Technology \& Society Magazine, 28(2), Summer, 16-22.

Palmater, P. (2011). Stretched beyond human limits: Death by poverty in First Nations. Canadian Review of Social Policy, 65/ 66, 112-127.

Rice-Green, J ., \& Dumbrill, G. C. (2005). A child welfare course for Aboriginal and nonAboriginal students: Pedagogical and technical challenges. J ournal of Technology in Human Services, 23(3/4), 167-181.

Robinson, M. (1992). Linking distance education to sustainable community 
development (Arctic Institute of North America Report 20). Calgary, AB. Retrieved from http:// www.eric.ed.gov/PDFS/ED400152.pdf

Royal Commission on Aboriginal Peoples (1996). People to people, nation to nation: Highlights from the report of the Royal Commission on Aboriginal Peoples. Ottawa: Minister of Supply and Services Canada.

Russell, C., Gregory, D., Hultin, D., Care, D., \&Courtenay, M. (2005, April). Cultures within cultures: Canadian Aboriginal students' experiences in online learning communities. Technologies, Colleges and Communities (TCC) Online Conference, Honolulu, Hawaii.

Sanchez, J., Stucky, M. E., \& Richard, M. (1998). Distance learning in Indian country: Becoming the spider on the web. J ournal of American Indian Education, 37(3 Spring), 5-7.

Sharpe, D. B. (1992). Successfully implementing a native teacher education program through distance education in Labrador. In D. Wall \& M. Owen (Eds.), Distance education and sustainable community development (pp. 75-85). Edmonton, AB: Canadian Circumpolar Institute with Athabasca University Press.

Sisco, A. (2010). Optimizing the effectiveness of e-learning for First Nations (The Conference Board of Canada, Report). Ottawa: Government of Canada.

Spronk, B. (1995). Appropriating learning technologies: Aboriginal learners, needs, and practices. Why the information highway? In J . Roberts \& E. Keough (Eds.), Lessons from open and distance learning (pp. 77-101). Toronto, ON: Trifolium Books.

Spronk, B., \& Radtke, D. (1988). Problems and possibilities: Canadian native women in distance education. In K. Faith (Ed.), Toward new horizons for women in distance education: International perspectives (pp. 214-228). London: Routledge.

Statistics Canada (no date). Population, urban and rural, by province or territory. 2006 census of Population.

Steele, N., \& Fahy, P. (2011). Attracting, preparing and retaining under-represented populations in rural and remote Alberta-North communities. IRRODL, 12(4). Retrieved from http:// www.irrodl.org/ index.php/irrodl/article/view/936/ 1838

Stonechild, B. (2006). The new buffalo: The struggle for post-secondary education in Canada. Winnipeg, Manitoba: University of Manitoba Press.

Tousignant, M., \& Sioui, N. (2009). Resilience and Aboriginal communities in crises: Theories and interventions. J ournal of Aboriginal Health, 5(1), 43-61. 
Voyageur, C. J . (2001). Ready, willing, and able: Prospects for distance learning in Canada's First Nations community. J ournal of Distance Education, 16(1), 102112.

Whiteduck, G., Tenasco, A., O’Donnell, S., Whiteduck, T. \& Lockhart E. (in press). Developing an e-community approach to community services in Kitigan Zibi Anishinabeg First Nation. J ournal of Community Informatics.

Woodman Simmonds, J ., Wasacase, T., \& O’Donnell, S. (2011). Post-secondary distance education for First Nations, Métis and Inuit Learners living in remoteand rural communities: An annotated bibliography. Fredericton: The VideoCom Project. Retrieved from http:// meeting.knet.ca/ mp19/mod/ book/view.php?id=1722\&chapterid=1354

Zapf, M. K., \& Bastien, B. (2000, May). The learning circle: A new model of BSW education for Alberta's rural, remote, and Aboriginal communities. In Issues Affecting Rural Communities (II). Proceedings of the International Conference on Rural Communities \& Identities in the Global Millennium. Nanaimo, British Columbia, Canada.

\section{Athabasca University $\mathbf{a}$}

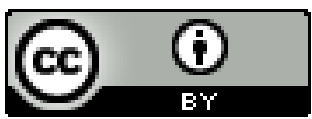

